\title{
The Effect of IFRS Application, Stock Price Volatility, and Fundamental Variables on Jakarta Islamic Index
}

\author{
Dellia Nurleli ${ }^{1^{*}}$, Masodah Wibisono ${ }^{2)}$ \\ ${ }^{1 *, 2)}$ Department of Accounting, Faculty of Economics, Gunadarma University \\ Jl. Margonda Raya No.100, Depok, Jawa Barat, 16424 \\ E-mail:dellianurleli@gmail.com ${ }^{1 *}$
}

\begin{abstract}
ABSTRAK
Tujuan dari penelitian ini adalah untuk menguji pengaruh penerapan IFRS, Volatilitas Harga Saham, Book to Market, Dividend Yield, dan Struktur Kepemilikan terhadap Return Saham. Metode pengambilan sampel yang digunakan adalah purposive sampling dan diperoleh sebanyak 14 perusahaan yang terdaftar di Jakarta Islamic Index (JII). Data diolah dan dianalisis dengan model uji statistik regresi linear berganda dan alat bantu SPSS Versi 23. Hasil dari penelitian ini menunjukkan bahwa secara parsial Volatilitas Harga Saham, Book to Market, dan Dividend Yield berpengaruh secara signifikan terhadap Return Saham. Sedangkan penerapan IFRS dan Struktur Kepemilikan tidak berpengaruh terhadap Return Saham. Secara bersama-sama penerapan IFRS, Volatilitas Harga Saham, Book to Market, Dividend Yield, dan Struktur Kepemilikan berpengaruh signifikan terhadap Return Saham.
\end{abstract}

Kata Kunci: IFRS; Saham; Volatilitas; Variabel Fundamental.

\begin{abstract}
The purpose of this study was to examine the effect of IFRS implementation, Stock Price Volatility, Book to Market, Dividend Yield, and Ownership Structure on Stock Returns. The sampling method used was purposive sampling and obtained 14 companies registered in the Jakarta Islamic Index (JII). The data were processed and analyzed by using multiple linear regression statistical test models and SPSS Version 23 as a tool. The results of this study indicate that partially the volatility of stock prices, book to market, and dividend yield has a significant effect on stock returns. Meanwhile, the implementation of IFRS and Ownership Structure has no effect on Stock Returns. Taken together, the implementation of IFRS, Stock Price Volatility, Book to Market, Dividend Yield, and Ownership Structure have a significant effect on Stock Returns.
\end{abstract}

Keywords: IFRS; Stock; Volatility; Variable Fundamental.

\section{INTRODUCTION}

According to Laksono (2015), the capital market is a place for long-term financial asset transactions. The development of the capital market, which is increasingly widespread and always changing rapidly, has a significant impact on the economy. Indonesia has a party that organizes and provides a system for buying and selling securities called the Indonesia Stock Exchange (IDX). Along with the increasing level of public knowledge regarding investment practices, there is a form of investment that is starting to attract many investors, namely investing in Islamic securities. 
The Indonesia Stock Exchange established the Jakarta Islamic Index (JII) since 2000. Where the JII was established with the aim of being a forum for companies with Islamic stocks. Registered companies have been screened first until they are finally determined to meet the criteria as companies with business processes that comply with Islamic sharia (Amalia and Kartikasari, 2016). JII filters companies that are in accordance with the sharia provisions based on liquidity and market capitalization value, so that in the end there are 30 Islamic stocks which are the most liquid stocks.

During the past few years, the Islamic capital market in Indonesia has developed very well. However, this is said to be still far from the optimal potential of the Islamic capital market. In fact, the OJK stated that the index for the level of public literacy regarding the Islamic capital market only reached 0.02 percent, while the inclusion of the Islamic capital market was 0.01 percent. Future research is expected to focus more on Islamic economics in order to improve the economy. Therefore, the main topic of this research is about the Islamic capital market, namely Stock Return on the Jakarta Islamic Index. Where according to Jogiyanto (2013), stock returns are defined as the results obtained from stock investments.

Each country has its own financial accounting standards that serve as guidelines. IFRS is a standard that applies in the global world, where with this standard management is required to provide estimates and logical judgments on financial statements. IFRS also demands a more complete disclosure of financial statements using a fair value approach, both qualitative and quantitative accounting information. With complete disclosure, transparency of a company's financial position, and presentation of reports in accordance with international accounting standards, this will increase investor interest. Where this will affect the company's returns. Research conducted by Feprida, Susilawati, and Koerniawan (2014) as well as Espinosa, Maquieira, Diaz, and Abarca (2015) states that there is a significant relationship between the application of IFRS and the level of stock returns, but other researchers such as Anggraeni and Koerniawan (2012) find a not significant between the two variables. H1: IFRS implementation affects stock returns.

According to Azzam (2010) risk is a negative return of an investment. One of the risks that must be accepted in capital market activities is the volatility of share prices. Price volatility is a dynamic variant of an asset and can be used for portfolio formation, risk management and price formation (Situmeang \& Muharam, 2015). When Volatility prices are high, the certainty to get Return is less and less. Low volatility indicates a stable stock return, although stable but generally the expected return at this point is quite low. Situmeang (2015) found a significant influence between stock price volatility and stock returns, this supports the 
research results of Baker et al (2011) which also found a significant influence between the two variables, however, Dimitrious (2011) revealed a significant negative effect in testing price volatility shares against stock returns. H2: Stock Price Volatility affect stock returns.

Other variables that can affect stock returns are the Book to Market ratio and Dividend Yield. The book to market ratio is a reflection of the comparison value between the book value of shares divided by the stock market value (Dormauli, 2017). Laksono (2015) said that a high Book to Market indicates that the company has poor performance and tends to experience financial difficulties. Book to Market has a significant effect on stock returns as shown in Dormauli's research (2017) but in Laksono's research (2015) it was found that Book to Market had no significant effect on stock returns. H3: Book to Market has an effect on stock returns.

Dividend Yield is the result of the percentage of profit per share divided by the price per share received in the company, the higher the dividend yield, the better the financial condition of the company, and this also shows that the company has a stable cash flow (Puspitasari and Purnamasari, 2013). Lemmon and Nguyen (2015) state that there is an effect of the Dividend Yield on stocks. Research by Zaman (2014) states that the dividend yield has no effect on stock returns. H4: Dividend Yield affects stock returns.

Internal factors of the company can also be used as variables that determine stock returns, one of which is company ownership. Institutional ownership is defined as ownership of company shares owned by institutions or institutions such as insurance companies, banks, other institutional companies (Murwanigsari, 2012). The results of research by Murwaningsari (2013) and Azzam (2010) found a significant positive relationship between company ownership and stock returns, while El-Masry (2017) found a negative result. H5: Ownership Structure affects stock returns.

Based on the explanation above, the authors take the sixth hypothesis as a whole namely H6: The Application of IFRS, Stock Price Volatility, Book to Market, Dividend Yield, and Ownership Structure together influence the Stock Return.

By paying attention to these factors, the researcher will test and find empirical evidence regarding the impact analysis of IFRS, Price Volatility, Dividend Yield, Book to Market, and Company Structure on Stock Returns. This research uses case studies of companies listed on the Indonesia Stock Exchange and is included in the Jakarta Islamic Index for the period 2015 - 2018. The object of this research is based on the importance of information needed in an increasingly developing capital market, besides that there are not too many researchers who have analyzed it deeper with the object of the Jakarta Islamic Index. 


\section{RESEARCH METHODOLOGY}

The design of this study is associative research (relationship), which is research that aims to determine the relationship between two or more variables. In this study, the samples used were companies registered in JII for four consecutive years from 2015 to 2018, and had complete data needed.

The source of data needed is financial data, where the authors download the financial data on the Indonesia Stock Exchange website and related company websites. The data that has been downloaded are then collected and entered into Microsoft Excel. After all data was collected, the authors processed the data using SPSS version 23 software. Types of data needed include percentage of IFRS application for IFRS variables, The company's stock price for Volatility variable stock prices and Dividend Yield, The book value of company shares for the Book to Market variable, the company's stock market value for the Book to Market variable, Dividend per share of a company for Dividend Yield variable, Total shares owned by the company for the variable Ownership Structure, and The company's total outstanding shares for the variable Ownership Structure

The analytical tool used in this study is the multiple linear regression. The data analysis method used are Descriptive Statistics Analysis which is a statistic used to analyze data by describing or describing data that has been collected as it is without intending to make conclusions that apply to the public or generalizes, Linearity Test which is interpreted as a relationship between variables such as straight lines or forms a linear line pattern, Classical Assumption Test considering the research data used is secondary, then to meet the requirements determined before the hypothesis test through the t-test and $\mathrm{F}$ test it is necessary to test some classic assumptions used, namely normality, multicollinearity, autocorrelation, and heteroscedasticity, and the last one is Hypothesis Test which is used to check or test whether the obtained regression coefficient is significant or not. Multiple regression models that can be used to test hypotheses are as follows:

$R S=a+b_{1} I F+b_{2} V H+b_{3} B M+b_{4} D Y+b_{5} S K+e$

Information:

RS (Stock Return), a (Constant), b1...5 (Linear Regression Coefficient), IF (IFRS), VH (Volatility), BM (Book to Market), DY (Dividend Yield), SK (Ownership Structure), and e (error).

Research Variables used in this study are IFRS (IF), Stock Price Volatility (VH), Book to Market (BM), Dividend Yield (DY), Ownership Structure (SK), and Stock Return (RS). Variable IFRS, the application of IFRS in this study is determined by the percentage of 
how much the application of PSAK is compared to the total PSAK. The percentage of IFRS implementation can be written in the formula:

IF $=\frac{\text { jumlah standar yang ditwapkan }}{44} \times 100 \%$

(Source: Ali A, 2016)

Variable Stock Price Volatility, One method for estimating stock volumes is historical volatility, namely, volatility calculated based on past stock prices, assuming that the behavior of stock prices in the past can reflect future stock behavior. In this formula $\mathrm{k}$ is the number of trading periods in one year. If the data is daily, then the daily trading period is $\mathrm{k}=252$. If the data is weekly, then the weekly trading period is $\mathrm{k}=52$, where the complete formula is:

$V H=\sqrt{\frac{\sum_{t-1}^{n}(k t-k t)^{2}}{k}}$

(Source: Situmeang, 2015)

Variable Book to Market is a reflection of the value of the comparison between the book value of shares divided by the stock market value. The book value explains the value of the company, which also describes the value of net worth compared to the number of shares outstanding.

$B M=\frac{\text { book vahe of equity }}{\text { stoek market price }}$

(Source: Dormauli, 2017)

Variable Dividend Yield is a way to determine how large a company is in comparing Dividends to shareholders seen from the current stock price. Systematically DY can be calculated as follows:

$D Y=\frac{\text { dividend per shawe }}{\text { stock market price }} \times 100 \%$.

(Source: Surya, 2018)

Variable Ownership Structure can be explained as the percentage of voting rights held by the institution. This variable is measured by the number of shares owned by the institution and the ownership of blockholders namely individual ownership or on behalf of individuals above $5 \%$ but not including insider ownership or manager at the end of the year.

$S K=\frac{\text { the number of shares of the ingtitution }}{\text { totat outstending shares }} \times 100 \%$

(Source: Riyansah and Suryana, 2016)

Variable Stock Return is the dependant variable in this study. According to Jogiyanto., 2013, Stock return (Rt) is the difference between the current share price (Pt) and the previous period stock price (Pt-1) divided by the stock price in the previous period (Pt-1). 
Return $=\frac{p_{t-P_{t-1}}}{p_{t-1}}$

(Source: Jogiyanto, 2013)

Based on the above hypothesis formulation and literature review, the framework of this study is as follows:

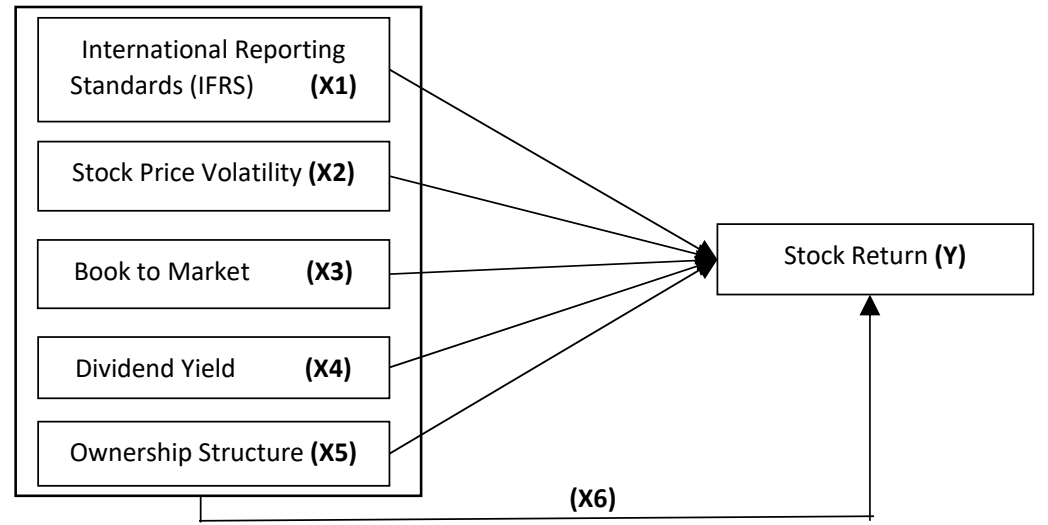

Figure 1. Framework Reseach

Source: Processed for this research (2019)

\section{RESULT AND DISCUSSION}

The sample used in this study were 14 companies registered in JII 2015-2018. Table I shows descriptive statistics on the variables of IFRS application, price volatility, book to market, dividend yield, ownership structure and stock returns. Based on Table I, the data that will be shown is $\mathrm{N}$, namely the number of samples in the study, Range, namely the difference between the highest and lowest values, Minimum, namely the lowest value, Maximum, namely the highest value, average, and std. Deviation.

Table 1. Descriptive Statistics Data

\begin{tabular}{lrrrrrr}
\hline & N & \multicolumn{1}{c}{ Range } & Minimum & Maximum & \multicolumn{1}{c}{ Mean } & \multicolumn{2}{c}{ Std. Deviation } \\
\hline IFRS & 56 &, 57 &, 14 &, 71 &, 4141 &, 60383 \\
VH & 56 & 4169,91 & 68,88 & 4238,79 & 839,0150 & 1028,16344 \\
BM & 56 & 116,82 &, 10 & 116,92 & 40,4993 & 27,98394 \\
DY & 56 & 6,12 &, 26 & 6,38 & 2,3284 & 1,35531 \\
SK & 56 &, 42 &, 39 &, 81 &, 5805 &, 11260 \\
Return & 56 & 2,83 &,- 54 & 2,29 &, 0316 &, 90431 \\
Valid N (listwise) & 56 & & & & &, \\
\hline
\end{tabular}

Source: Data processed, 2019

Based on the results of descriptive analysis in Table 1 , it can be seen that $\mathrm{N}$ is 56 , this is because there are 14 companies included in this study and 4 years of data collection for 
each company. In Table I, IFRS has an average (mean) of 0.4141 . The maximum value is 0.71 , while the minimum value is 0.14 . The volatility variable has an average (mean) of 839,0150 . The maximum value for this variable is 4238.79 , while the minimum value is 68.88. The book to market variable has an average of 40.4993 . The maximum value is 116.92 and the minimum value is 0.10 . Dividend Yield has an average of 2.3284. The maximum value is 6.38 and the minimum value is 0.26 . The ownership structure variable has an average value of 0.5805 . The maximum value is 0.81 and the minimum value is 0.39 .

Table 2. Results of Multiple Regression

\begin{tabular}{|c|c|c|c|c|c|c|}
\hline \multirow[b]{2}{*}{ Model } & & \multicolumn{2}{|c|}{ Unstandardized Coefficients } & $\begin{array}{c}\text { Standardized } \\
\text { Coefficients }\end{array}$ & \multirow[b]{2}{*}{$\mathrm{t}$} & \multirow[b]{2}{*}{ Sig. } \\
\hline & & $\mathrm{B}$ & Std. Error & Beta & & \\
\hline \multirow[t]{6}{*}{1} & (Constant) &,- 590 &, 503 & &, 118 & ,907 \\
\hline & IFRS & ,209 & 017 &, 005 &,- 031 & ,975 \\
\hline & Trans_VH &,- 804 & ,738 &,- 304 & $-3,027$ &, 004 \\
\hline & $\mathrm{BM}$ &,- 484 & ,302 &,- 267 & $-2,832$ & ,017 \\
\hline & Trans_DY &, 134 & ,218 &, 161 & 2,870 & ,032 \\
\hline & SK &,- 070 & 035 &,- 020 &,- 130 & ,897 \\
\hline
\end{tabular}

a. Dependent Variable: Return

Source: Data Processed, 2019

Based on the results of the analysis of Table 2, an equation model can be made based on the unstandardized coefficient and the contribution of the independent variable in explaining the dependent variable based on standardized coefficients. The equation model based on Unstandardized Coefficients is as follows:

$\mathrm{RS}=-0,590+0,209 \mathrm{IF}-0,804 \mathrm{VH}-0,484 \mathrm{BM}+0,134 \mathrm{DY}-0,070 \mathrm{SK}+\mathrm{e}$.

This test uses a significance level of $5 \%(0.05)$. If the significance value is less than 0.05 then there is a significant effect between all independent variables on the dependent variable. Based on the results of testing partially on table above, it shows that IFRS and Ownership Structure has no effect on Return, while Volatility Price, Book to Market and Dividend Yield has an effect on Stock Return.

Table 3. Coefficient Test Result $R, \mathbf{R}^{2}$, dan Adjusted $\mathbf{R}^{2}$

\begin{tabular}{|c|c|c|c|c|}
\hline Model & $\mathrm{R}$ & R Square & Adjusted R Square & Std. Error of the Estimate \\
\hline 1 &, $572^{\mathrm{a}}$ & ,327 & 259 & ,399629 \\
\hline
\end{tabular}

a. Predictors: (Constant), SK, BM, Trans_DY, IFRS, Trans_VH

Source: Data Processed, 2019

In Table III it can be seen that the $\mathrm{R}$ value in this coefficient test is 0.572 , which indicates that the relationship between the IFRS, VH, BM, DY, and SK variables on the 
Return variable is quite strong and positive. The value of R2 (coefficient of multiple determination) is $32.7 \%$ which indicates that the Return variable described by this research model is based on the independent variables used in this study of $32.7 \%$. While the rest, $67.3 \%$ is explained by other independent variables outside the independent variables in this study. The adjusted R2 value is $25.9 \%$, indicating that the independent variables used in this study can predict $25.9 \%$ return.

Table 4. F Test Results

\begin{tabular}{llrrrrr}
\hline Model & & Sum of Squares & df & \multicolumn{1}{c}{ Mean Square } & F & \multicolumn{1}{c}{ Sig. } \\
\hline 1 & Regression &, 466 & 5 &, 153 & 3,960 &, $001^{\mathrm{b}}$ \\
& Residual & 7,985 & 50 &, 160 & & \\
& Total & 8,431 & 55 & & & \\
& & & & & &
\end{tabular}

a. Dependent Variable: Return

b. Predictors: (Constant), SK, BM, Trans_DY, IFRS, Trans_VH

Source: Data Prosessed, 2019

The role of this test is to examine the significance of the effect of IFRS, VH, BM, DY, and SK together on Return. This test uses a significance level of 5\%. If the significance value $<0.05$, then there is an influence between all independent variables on the dependent variable. Based on the results of the simultaneous testing, the effect of IFRS, VH, BM, DY, and SK together on Return in table IV, obtained a significance value of 0.001 . This means that the significance value is lower than $0.05(0.001<0.005)$. This shows, that IFRS, VH, BM, DY, and SK jointly influence Return.

From the results of tests conducted on the regression model, it is known that the significance value of IFRS is 0.975 which is greater than 0.05 . The IFRS regression coefficient presented in table is 0.209 . It can be concluded, that there is no influence between the applications of IFRS (X1), as measured by the percentage of PSAK applied, to Stock Return. The result of this study are in line with research by Anggraeni (2012), Espinosa (2015), but not in line with research by Feprida and Koerniawan (2014). This is because IFRS is an international accounting standard adopted by several countries in the world. IFRS regulates accounting and reporting standards for companies to improve the quality of these companies. But not all types of businesses have the same standards for accounting and reporting, for example, companies that have Islamic shares. Companies that have sharia links have different standards, namely Accounting \& Auditing Organization for Islamic Financial Institutions (AAOIFI). 
The object of this research is a company registered in the Jakarta Islamic Index (JII), which means that the company has sharia instruments, but these companies do not apply sharia standards as they should. For now, AAOIFI is only applied to financial institutions. Another reason companies that have sharia shares do not use these sharia standards is because the operational basis of the company is not based on sharia, so there is no obligation in implementing AAOIFI standards. Even so, IFRS cannot regulate according to Islamic Sharia standards so IFRS cannot be said to affect stock returns in this study.

From the results of tests conducted on the regression model, it is known that the significance value of Volatility is 0.004 which is lower than 0.05 . This can be concluded, that there is an influence between Volatility Stock Prices (X2), which are measured based on fluctuations in the company's stock price, on Stock Return. If seen in the coefficient, VH has a negative coefficient. This shows that there is a negative influence between Volatility Stock Prices on Return. High volatility provides high risk, this causes investors to dislike stocks with high volatility. Long-term investors generally prefer stocks with low volatility, which have good stability (Situmeang, 2015). This theory supports the data for this research. The result of this study are in line with Dimitrios and Theodore (2011) but contradict the research by Situmeang (2015).

From the results of tests conducted on the regression model, it is known that the significance value of Book to Market is 0.017 which smaller than 0.05. It can be concluded, that there is an influence between Book to Market (X3), as measured by the distribution of book value of shares with market prices, on Stock Return. When viewed from the coefficient, $\mathrm{BM}$ has a negative coefficient of 0.484 . That is, the higher the level of BM, the company's return tends to decrease. Book to Market ratio is a ratio used as an indicator to measure a company's performance through its market price. A high book to market ratio indicates that the company has poor performance and tends to experience financial difficulties (financial distress) or has unfavorable prospects (Laksono, 2015). The high indication of financial difficulties causes stock returns to decline and investors are reluctant to invest in shares of companies with high levels of financial difficulties. The results of this study are supported by Dormauli (2017) regarding the negative influence of Book to Market on Return. They explained that efficient investors would combine small companies and have low book-tomarket value to get superior risk-adjusted returns. This result contradict Laksono (2015).

From the results of tests conducted on the regression model, it is known that the significance value of Dividend Yield is 0.032 which is smaller than 0.05 . It is concluded that there is an influence between Dividend Yield (X4), which is measured based on the division 
between Dividends per share and market price of shares, on Return. When viewed from the coefficient, DY has a positive coefficient of 0.134 . That is, the higher the DY level, the company tends to get a high return as well. Puspitasari \& Purnamasari (2013) said, the higher the value of DY, the better the company's financial condition and shows a stable cash flow. DY is one of the important ratios when analyzing stocks when going to invest because when investors invest in companies that have a high DY value means investors invest in companies with good and stable financial conditions. The possibility of getting a return on shares is also stable. This is consistent with the theory that a stock with a higher dividend yield will be more attractive to investors, which will increase share prices, which in turn will result in higher returns for investors. The result of this study support the research of Michael L. Lemmon and Thanh Nguyen (2014), Puspitasari and Purnamasawi (2013), Surya (2018). But it is not in line with Zaman (2014).

From the results of tests conducted on the regression model, it is known that the significance value of Ownership Structure is 0.897 which is greater than 0.05 . It can be concluded, there is no influence between Ownership Structure (X5), which is measured based on the percentage of shares owned by the company and all existing shares, on Return. When viewed from the coefficient, SK has a negative coefficient of 0.070 . That is, the higher the SK level, the company tends to get a lower return. According to El_ansary and Atuea (2012), one of the reasons that make the SK variable insignificant is because it has inefficient information, causing speculative trading. Thus, it is very difficult to rely on the SK variable to explain the variation of Return that occurs. In addition, stock market performance is mainly influenced by economic and market conditions compared to the Ownership Structure variable.

The results of this study indicate that SK has a weak influence on Return, this can also be caused by companies listed on JII have the same character in terms of Ownership Structure, the data obtained for the Ownership Structure variable during the research year is relatively homogeneous, namely elements of the data studied are relatively uniform with each other. In the variable data, generally most of the companies in this study has not changed its number for four conservative years, 8 of the 14 total companies in this study have the same number for four years for the SK variable. While other companies experienced small changes in the percentage. Due to the fact that the data are mostly the same, it is difficult to find a significant influence between SK and Return. The results of the research also show that companies listed in JII have the same character in terms of ownership structure. This has led to the results of the research output stating that SK has no significant effect on Return. The 
results of this study are in line with research by Riyansah (2016) but cotrary to research by Murwaningsih (2012), Ahmed A (2017) and Azzam (2010).

From the results of tests conducted on the regression model, it is known that the significance value of implementation of IFRS, Volatility price, Book to Market, Dividend Yield, and Ownership Structure jointly is 0.001 which is smaller than 0.05 . It can be concluded that the application of IFRS, Price Volatility, Book to Market, Dividend Yield and Ownership Structure together (simultaneously) affects Return. In table II, the constant number is -0.590 , which shows that if there are no independent variables (IFRS, VH, BM, DY, and $\mathrm{SK}=0$ ), the Return value is -0.590 . In table III it can be seen that the value of $\mathrm{R}$ in this coefficient test is 0.572 , which indicates that the relationship between IFRS, VH, BM, DY and SK variables on Return is quite strong and positive. The value of R2 is 0.327 or $32.7 \%$, which indicates that the Return variable explained by this research model based on the independent variables used in this study amounted to $32.7 \%$. While the remaining $67.3 \%$ cannot be explained in the model or explained by error factors or in other words the rest can be explained by independent variables outside the variables mentioned in this study. While the Adj R2 value of $22.4 \%$, shows that the independent variables used in this study can predict $22.4 \%$ Return.

The results of this study are said to be reliable because the data used is valid data that comes from trusted sources and several tests have been carried out beforehand so that the effect test between variables can be carried out. Overall the results of this research can also be carried out for other objects, for example using conventional companies and not having any connection with sharia regulations. In this study, there is an anomaly due to the limitation on sharia criteria and a short year limitation, therefore one of the variables is considered to be less able to explain its relationship to stock return partially. It is hoped that further research will use a longer year to solve this problem and also carry out research with a wider object.

\section{CONCLUSIONS AND RECOMMENDATIONS}

Based on the result of this research, we can conclude that partially the application of IFRS and Ownership Structure does not affect stock returns. While Stock Price Volatility, Book to Market, and Dividend Yield have a significant effect on Stock Return. This study also indicate that the application of IFRS, Stock Price Volatility, Book to Market, Dividend Yield, and Ownership Structure simultaneously influence the Stock Return.

There is no influence between the application of IFRS and Return. This is because even though the application of IFRS can improve the quality of corporate financial statements 
and relations with investors, in fact, the influence of IFRS is less significant in influencing sharia-based shares. IFRS accounting and auditing standards that apply to conventional. Sharia standardization is regulated in the Accounting \& Auditing Organization for Islamic Financial Institutions (AAOIFI), but unfortunately, this sharia standard has only recently been implemented by the banking world, companies that have sharia shares have not used this standard. Nevertheless, IFRS on its basis cannot cover the Islamic Shari'a as it should, therefore, the application of IFRS has no significant effect on Stock Return.

There is a negative influence between Volatility Price on Stock Return. The level of risk faced by investors reflects the level of Volatiles in the financial markets. High Return uncertainty is influenced by high Volatility, meaning that if Volatility is high every day, the company will experience a high increase and decrease, in other words, the company can generate large profits or losses. This is because the higher the volatility, the higher the risk inherent. The fact is investors want stability Returns with a small risk, this will be obtained by companies that have low volatility. Therefore a low volatility equal to high Stock Return.

There is a negative influence between Book to Market and Return. This is because Book to Market is used as an indicator to measure company performance, where the higher the Book to Market, the company has a poor performance and causes stock returns to decline. The average $\mathrm{BM}$ value during the observation period always increases and this results in a decrease in average Returns during the related years.

There is a positive influence between Dividend Yield and Return. This is because of the higher the DY value the better the financial condition of the company and shows a stable cash flow. A good financial condition will attract more investors where it will lead to rising stock prices, which in turn will result in a higher return. In fact, in each observation year (2015 - 2018), the highest DY value will have a greater Return value than companies that have a low DY value.

There is no influence between ownership structure and return. This is caused by field data that is homogeneous so it is difficult to find a significant relationship between SK and Return. During the 2015 - 2018 observation year, it was found that eight companies had the same SK value for four consecutive years, while other companies experienced small changes. The constant SK value and the movement of stock returns conclude that the effect that the SK has on Stock Return is small.

There is an influence of IFRS, Volatile Prices, Book to Market, Dividend Yield, and Ownership Structure with Stock Return simultaneously. This is because the company's 
fundamental factors and market risk management is an attempt to obtain the optimal value of the company's stock return.

Some limitations in this study are this research only has a four-year study period and this research is limited in the selection of samples only to companies listed in the Jakarta Islamic Index (JII). Therefore the suggestions that can be given for further researchs are to use a larger number os samples, namely using a sample of all companies outside the list of JII. Further research can also use a longer research period and are expected to use more independent variables to enabled a greater influance on stock returns.

\section{BIBLIOGRAPHY}

Alnodel, Ali A. (2016). The Effect of the Adoption of IFRS on Capital Market Integration of GCC Countries. Journal of International Accounting Research (JIAR). 6 (4)

Amalia, Arisa Dwi and Kartikasari, Dwi. (2016). Analisis Perbandingan Kinerja Saham Perusahaan Manufaktur Terindeks Syariah dan Konvensional. Jurnal Akuntansi, Ekonomi dan Manajemen Bisnis. p-ISSN: 2337-7887.

Anggraeni, Desy and Koerniawan, Koenta Adji. (2012). Perbandingan Laporan Keuangan (Laporan Laba Rugi) Sebelum dan Sesudah Penerapan Ifrs Serta Pengaruhnya terhadap Return Saham pada Perusahaan Manufaktur. 8 (2)

Azzam, Islam. (2010). The Impact of Institutional Ownership and Dividend Policy on Stock Returns and Volatility: Evidence from Egypt. International Journal Of Business. 15 (4). ISSN: 1083-4346.

Baker, Maloclm P., Bradley, Brendan., and Wurgler, Jeffrey. (2011). Benchmarks as Limits to Arbitrage: Understanding the Low-Volatility Anomaly. NYU Working Paper No. 2451/29593.

Dimitriou, Dimitrios dan Simos, Theodore. (2011). The Relationship between Stock Returns and Volatility in the Seventeen Largest International Stock Markets: A Semi-Parametric Approach. Modern Economy. 2. 1-8.

Dormauli, Justina. (2017). Book to Market. Pengaruh Firm Size dan Market to Book Ratio terhadap Return Portofolio. Jurnal Manajemen dan Bisnis Sriwijaya. 15 (2)

El-Masry, Ahmed A. (2017). Effect of Ownership Structure on Firm Stock Return Performance: Evidence from the Egyptian Stock Market. International Research Journal of Finance and Economics. ISSN 1450-2887.

Espinosa, Christian., Maquieira, Carlos., Diaz, Fernando., and Abarca, Allyson. (2015). Adoption of IFRS in an emerging market: the Chilean case, Academia Revista Latinoamericana de Administración, 28 (4), 442-460.

Feprida, Susilawati and Koerniawan. (2014). Perbandingan Laporan Perubahan Ekuitas Sebelum dan Sesudah Penerapan Ifrs serta Pengaruhnya terhadap Return Saham pada Perusahaan Manufaktur yang Listing Di BEI. Jurnal Riset Mahasiswa Akuntansi Unikama. p-ISSN 23375663.

Hendrata, Adi Surya. (2018). Pengaruh Dividend Yield terhadap Return Saham serta Mediasi Price Earning Ratio dan Dividend Payout Ratio pada Pengaruh Earning Per Share terhadap Return Saham. Skripsi. Universitas Sanata Dharma. Yogyakarta.

Jogiyanto Hartono. (2013). Metodologi Penelitian Bisnis: Salah Kaprah dan PengalamanPengalaman. BPFE Yogyakarta. Yogyakarta.

Laksono, Yogo. (2015). Analisis Pengaruh Beta, Size, Book To Market, dan Profitability terhadap Return Aggresive Stock (Studi Kasus Pada Indeks Saham Kompas 100 pada Pasar Modal Indonesia Periode 2009 - 2013). Journal of Management. 4 (4) 
Laksono, Yogo. (2015). Analisis Pengaruh Beta, Size, Book To Market, dan Profitability terhadap Return Aggresive Stock (Studi Kasus pada Indeks Saham Kompas 100 pada Pasar Modal Indonesia Periode 2009 - 2013). Journal of Management. 4 (4)

Lemmon, Michael L., and Thanh Nguyen. (2015). Dividend Yields and Stock Returns in Hong Kong. Managerial Finance. 41 (2). 164-181.

Murwaningsari, Etty. (2012). Pengaruh Struktur Kepemilikan Terhadap Return Saham. Jurnal Media Riset Akuntansi, Auditing \& Informasi. p-ISSN 1411-8831.

Puspitasari, Anggraeni dan Purnamasari, Linda. (2013). Pengaruh Perubahan Dividend Payout Ratio dan Dividend Yield terhadap Return Saham (Studi Pada Perusahaan Manufaktur di Bursa Efek Indonesia). Journal of Business and Banking. 3 (2)

Riyansah, Rama and Suryana. (2016). Pengaruh Struktur Kepemilikan Institusional, Agency Cost, Leverage, Corporate Social Responsibility terhadap Return Saham pada Perusahaan yang Terdaftar Di Indeks Lq45 Periode 2011-2015. Skripsi. Universitas Widyatama. Bandung.

Situmeang, Santa dan Muharam, Harjum. (2015). Analisis Pengaruh Volatilitas Harga, Likuiditas Saham, Eps, Size Firm, Momentum Overnight terhadap Return Saham (Studi kasus perusahaan yang terdaftar dalam Indeks LQ45 Periode 2009-2013). Diponegoro Journal Of Management. 4 (3). 1-12.

Sugiyono. (2014). Metode Penelitian Pendidikan Pendekatan Kuantitatif, Kualitatif, dan R\&D. Bandung: Alfabeta.

Zaman, Rashid. (2014). Impact of Dividend Yield and Price Earnings Ratio on Stock Returns: A Study Non-Financial listed Firms of Pakistan. Research Journal of Finance and Accounting. 5(19). 68-74. 